pendent measurement of wind speed was made, using metal strips ejected from the rocket and tracking them with radar.

Results were shown of wind and tempcrature profiles up to a height of $95 \mathrm{~km}$. above the ground. Radio-sondo ascents provided the data for the first $30 \mathrm{~km}$. The agreements in the region of overlap between the sonde data and the data from the grenade experiments were good, of the order of 2 motres per sec. for the wind-speed and $2^{\circ} \mathrm{C}$. for the temperature. Similar agrcement was found between wind-speeds measured by the grenade experiment and by the radar tracking of the metal strips.

W. E. SCHOHES

\title{
SCIENCE IN GRAMMAR SCHOOLS
}

A BOOKLEI', "The Provision and Maintenance of Laboratories in Grammar Schools (1959)", reports the results of a survey on science in grammar schools conducted by means of a questionnaire issued by a number of teachers' organizations during $1959^{*}$. The booklet reveals some improvemonts following an earlier survey in 1957, but shows that many critical difficulties still remain.

Replies wore analysed from 694 grammar schools, widely distributed over England and Wales, and totalling, between them, 374,000 pupils. Analysis revealed that, genorally speaking, boys' and mixed achools were better provided with facilities for science than girls' schools.

91.4 per cent of the pupils took science, compared with 90.9 per cent in 1957. During the first three years almost all pupils do some science. In the fifth year, when the examination for the Ordinary Level, General Certificate of Education, is usually taken, about 90 per cent of the pupils are taking science, In the sixth form, in girls' schools, the proportion studying science - including those who are not specializing in it-can be as low as 46 per cent, and in boys' schools as low as 66 per cent. When the sixth formors who are specializing in science are examined in girls' achools, the number of pupils is less than half that in the boys' schools (which is about 60 per cent); in mixed schools the position is somowhat in between.

Between 1957 and 1959 there was a small increase in the size of sixth-forms. Nevertheless, statistics showing the average size of the seience sixth-forms of smaller girls' and mixed schools suggest that some sohools still have uneconomically small sixth-forms.

Boys' sehools tend to concentrate on physics and chemistry, and girls' schools on biology. General science has lost further ground, being a bad fourth after the three individual subjects. From a total of 13,626 pupils whose science subjects were examined, physics had established itself as the most widely taken subject with 10,619 sixth-formers. Next comes chemistry with 8,603 , biology with 2,091 ,

- Science Masters Association. Pp. I6. (Iondon: John Murray ; published for the Science Masters Association, 1960.) 18, net. zoology with 1,987 , botany with 1,430 and geology with 146 .

Only 45 per cent of 547 local oducation authority schools have laboratory provision in accordance with Ministry of Education recommendations, compared with 44 per cent in 1957. Throughout England and Wales the number of new laboratories and laboratories commenced during 195859 totals 486 in these schools. Permission has been given for the future building of 482 more laboratories. Even when this work is completed, the laboratory position in local education authority grammar schools will still fall fur short of that in direct grant and independont schools.

Direct grant and independent boys' schools have inereased thoir provision of laboratory assistance since 1957, but the position for the local education authority schools, as shown in the sample 568 examined, indicates a slight regression. By using standards of laboratory space recommended by the Ministry, and the number of technicians per number of laboratories considered necessary by the Seience Mastors' Association, only 10 per cent of local education authority grammar schools can be said to be satisfactorily provided with laboratory assistance.

The following table shows the amounts spent per annum for each pupil taking science, averaged for sehools of stated types:

\begin{tabular}{|c|c|c|c|c|}
\hline $\begin{array}{l}\text { Total No. } \\
\text { of schools } \\
\text { in sample }\end{array}$ & Type of school & Boys & Girls & Mixed \\
\hline $\begin{array}{r}578 \\
54 \\
43 \\
12\end{array}$ & $\begin{array}{l}\text { Local Education } \\
\text { Authority Grammar } \\
\text { Direct grant } \\
\text { Independont } \\
\text { Comprehensive }\end{array}$ & $\begin{array}{l}12 s .3 d . \\
21 s .11 d . \\
278.1 d\end{array}$ & $\begin{array}{l}8 s .8 d \\
8 s .3 d \\
98.8 d \\
\end{array}$ & $\begin{array}{c}10 s .10 d . \\
\overline{48.9 d} .\end{array}$ \\
\hline
\end{tabular}

Additional problems mentioned by the greatest number of schools are as follows: lack of science staff (124 schools); very large classes (197); staff not appropriately qualified (72); more laboratory stewards needed (68); sixth-form accommodation inadequate (46); practical work very limited (31).

\section{STATISTICS ON SPECIAL EDUCATION}

$\mathrm{T}$ HF term 'special eduoation' has been used in educational literature to refer to the "education of pupils who deviate so far physically, mentally, emotionally, or socially from the relatively homogeneous groups of so-called 'normal' pupils that the standard curriculum is not suitable for their educational needs ; involves the modification of the stand- ard curriculum in content, methods of instruction, and the expected rate of progress to provide optimum educational opportunity for such pupils; carried on in special classes, in special curricula, or special schools".

In the first Unoseo questionnairo on educational organization and statistics, distributed in 1949 , 
data under 'special education' were requested covering "institutions of a specialized nature intended for children handicapped physically, mentally and morally". Continued experience of gathering educational statisties and of dealing with problems connected with international statistical comparisons led to various specifications of the term, from the recommendation of the first Expert Committee on Standardization of Educational Statistics in 1951 to classify "all general or vocational education given to physically or mentally handicapped socially maladjusted, retarded or backward persons" as "Special education", to the recommendation concerning the international standardization of educa. tional statistics adopted by the general conference of Unesco at its tenth session, held in Paris in December 1958. This asked that statistics be presented on "Special Education, covering all general or vocational education given to children who are physically handicapped, mentally handicapped, socially maladjusted or are in other special categories".

Unesco's only statistical questionnaire devoted to the special education of handicapped and other atypical children was sent out at the end of 1953. The term 'special education' was "to cover the training whether in special schools or in special classes in the regular schools of the country, of children who: (1) require special provision for predominantly mental, or psychological, disability; (2) require special provision for predominantly physical disability ; (3) have no fixed home ; (4) are in correctional institutions".

The next Unesco collection of statistics on the education of atypical children was made when a general questionnaire on all levels of education was gent out in 1955. It was stated that "special education covers pre-school, primary and secondary schools for mentally handicapped children, for physically handicapped children ; for delinquent children". It also covers special classes for similar groups of children in regular schools.

The replies to these questionnaires showed considerable variation as to both schools and classes. A few countries considered the education of highly intelligent children to be part of spscial education (for example, Australia, Canada, the United States of America). A smaller number of countries (for example, Belgium and the Netherlands) considered education of itinerant children as part of special education. Schools for juvenile delinquents and schools for abandoned or neglected children were sometimes included, sometimes not included.

In the latest report, all those types of education have been included, in a particular country, as part of 'special education' of atypical children*. When possible, schools which were not considered in the particular country as providing special education, but which were so considered in other countries and which had certain features that marked them off notably from other schools providing courses at a similar level, were also ineluded. In practice, these schools were most often schools for delinquent children. On the other hand, no attempt was made to include courses of correspondence education, although they have often been used for instruction of handicapped children.

Certain institutions the function of which is not principally educational-homes for children, observation centres-have been included on occasion, usually because in the country itself the institution was considered as having a special educational role.

Statistical tables, arranged on a country-by-country basis, are presented for 53 countries. For certain other countries little information was available, and is included separately.

- UNESCO. Statistics on Special Education. (Statistical Reports and Studies.) Pp. 154. (Paris : UNESCO; London : H.M. Stationery Office.) 7 NF.; 10s.; 2 dollars.

\section{RECRUITMENT TO THE CIVIL SERVICE}

\begin{abstract}
THE ninety-fourth report of the Civil Service Commissioners*, covering the year April 1, 1959-March 31, 1960, in which Sir Frederick Brundrett succeeded Sir Charles Snow as scientific adviser on the latter's resignation, notes some signs of improvement in recruitment to the Administrative Class. The results of the competitions for posts in Branch $A$ of the Foreign Service were also much better than recently, and after filling the advertised vacancios there was a small surplus of acceptable candidates available to help make good shortages in past recruitment. Nevertheless, both the Administra. tive Class of the Home Civil Service and the Senior Branch of the Foreign Service need to recruit directly a larger number of men and women than has been possible recently, and the upper age limit for entry to the open competitions for these classes is being raised from 24 to 28 in 1961, and also for the related competitions for the Special Departmental Classes.

The most important feature of the year, however, was the continued difficulty in recruitment to the

* Report of Her Majesty's Civil Service Commissioners for the period 1st April, 1959, to 31st March, 1960. (94th Report.) Pp. 39. (London: H.M. Stationery Office, 1960.) 28. $6 d$. net.
\end{abstract}

scientific, professional and technical classes. For some years the Commissioners have failed to fill an adequate proportion of the vacancies notified in the scientific classes, especially in the scientific officer grade. During 1959-60 the situation has worsened and the Commissioners regard the present situation with grave disquiet. The number of applications in open competitions for nearly all the scientific classes increased, but the average quality of these candidates, especially for the scientific officer and senior scientific officer grades, has noticeably deteriorated. In spite of a small increase in the number of applications in the senior scientific officer grade and in the number recruited, namely, 70, little more than half the 115 vacancies were filled; and in the scientific officer grade only 60 were recruited to fill 380 vacancies. The shortages are mainly among physicists, engineers, chemists and mathematicians.

There was a slight increase in the number of candidates for the experimental officer/assistant experimental officer grades, but the number who were successful remained steady, and only 102 out of 117 vacancies in the former and 297 out of 404 in the latter class were filled. The number of applications for the assistant (scientific) class decreased 